\title{
Genetic effects conferring heat tolerance in upland cotton (Gossypium hirsutum L.)
}

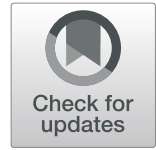

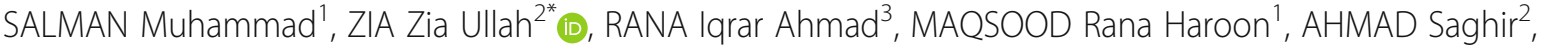 \\ BAKHSH Ali ${ }^{4}$ and AZHAR Muhammad Tehseen ${ }^{1}$
}

\begin{abstract}
Background: Climate change and particularly global warming has emerged as an alarming threat to the crop productivity of field crops and exerted drastic effects on the cropping patterns. Production of cotton has been dropped down to one million bales from 1.4 million bales since 2015 in Pakistan due to the increase in temperature at critical growth stages, i.e., flowering and boll formation. Keeping in view the importance of cotton in the country, this study was conducted to investigate the genetic effects conferring heat tolerance in six populations $\left(\mathrm{P}_{1}, \mathrm{P}_{2}, \mathrm{~F}_{1}, \mathrm{~F}_{2}, \mathrm{BC}_{1}\right.$ and $\left.\mathrm{BC}_{2}\right)$ developed from cross- 1 and cross-2, i.e., $\mathrm{VH}-282 \times \mathrm{FH}-142$ and DNH-40 $\times$ VH-259.

Results: The results revealed that cross-1 performed better in heat stress as compared with cross-2 for majority of the traits recorded. Boll weight and ginning outturn (GOT) were highly effected under heat stress and had negative correlation with Relative cell injury (RCI). Boll weight, fiber length, fiber strength and fiber fineness were under the control of non-additive gene action, whereas $\mathrm{RCl}$ was controlled by additive gene effects. Lower values of genetic advance coupled with higher values of broad sense heritability for these traits except RCI confirmed the role of non-additive genetic effects. Duplicate types of epistasis were recorded for fiber strength in cross-1 in normal condition. However, complementary type of non-allelic interaction was recorded for fiber strength under normal condition, fiber fineness and $\mathrm{RCl}$ under heat stressed condition in cross-1. Likewise, boll weight, GOT and fiber length in populations derived from cross-2 in normal condition were also under the influence of complementary type of non-allelic interaction. Significant differences among values of mid parent and better parent heterosis for boll weight in both normal and heat stress condition provided the opportunity to cotton breeders for utilization of this germplasm for improvement of this trait through exploitation of heterosis breeding.

Conclusion: Cross-1 performed better in heat stress and could be utilized for development of heat tolerant cultivar. RCl was under the influence of additive gene action, so one can rely on this trait for screening of large number of accessions of cotton for heat stress. While other traits were predominantly controlled by non-additive gene action and selection based on these should be delayed in later generations.
\end{abstract}

Keywords: Heat stress, Heritability, Heterosis, Relative cell injury, Upland cotton

\footnotetext{
* Correspondence: zia_pbg@yahoo.com

${ }^{2}$ Cotton Research Institute, Multan, Pakistan

Full list of author information is available at the end of the article
}

(c) The Author(s). 2019 Open Access This article is distributed under the terms of the Creative Commons Attribution 4.0 International License (http://creativecommons.org/licenses/by/4.0/), which permits unrestricted use, distribution, and reproduction in any medium, provided you give appropriate credit to the original author(s) and the source, provide a link to the Creative Commons license, and indicate if changes were made. The Creative Commons Public Domain Dedication waiver (http://creativecommons.org/publicdomain/zero/1.0/) applies to the data made available in this article, unless otherwise stated. 


\section{Background}

Cotton belongs to family Malvaceae containing more than 200 genera and about 2300 species. There are more than 50 species of Gossypium reported till now, which are native to Africa, Australia, Central and South America and Asia, respectively (Fryxell 1992; Wendel and Grover 2015). Out of 50 species, only four are domesticated and widespread. Two diploid $(2 \mathrm{n}=26)$ species, namely G. arboreum and $G$. herbaceum belong to Old World cotton produce only $1 \%$ of the total cotton production in the world, whereas two tetraploid $(2 n=52)$ species, namely G. barbadense and G. hirsutum belong to New World cotton produce $94 \%$ of the total world cotton production. G. barbadense produces $4 \%$, while G. hirsutum also known as upland cotton produces about $90 \%$ of the total cotton production in the world (Lu et al. 1997; McCarty et al. 2004).

Upland cotton is a key source of spinnable fiber and cultivated in more than 61 countries in the world on an area of 29.3 million hectares (ICAC 2018). Cotton and cottonbased industry has a pivoting role in the economy of Pakistan. Pakistan ranks the fourth in terms of area and production in the world after India, China and USA, 3rd in consumption and 2nd in yarn production in the world. Cotton contributes 1\% share in GDP, while 55\% in total foreign exchange earnings of Pakistan. Cotton was planted on an area of 2.7 million hectares in 2017, showing an increase of $10 \%$ over the previous year. About $8 \%$ more cotton production, i.e., 11.54 million bales was recorded during 2017/ 2018 as compared with 2016/2017 where 10.72 million bales was recorded (PCCC 2017). However, in terms of per acre yield $\left(679 \mathrm{~kg} \cdot \mathrm{hm}^{-2}\right)$, Pakistan is lagging far behind from the major cotton producing countries like Australia (1 $816 \mathrm{~kg} \cdot \mathrm{hm}^{-2}$ ), China $\left(1719 \mathrm{~kg} \cdot \mathrm{hm}^{-2}\right.$ ), Turkey (1 826 $\mathrm{kg} \cdot \mathrm{hm}^{-2}$ ) and USA $\left(985 \mathrm{~kg} \cdot \mathrm{hm}^{-2}\right)$ (ICAC 2018).

A loss of about one-third of cotton produce was recorded in Pakistan during 2015/2016 due to adverse climatic conditions particularly heavy rains during reproductive phase of crop. But high temperature with dry weather conditions favored the spread of whitefly in 2016 and 2017 which affected the productivity of cotton crop on a wide range of area in Punjab province. In recent times besides drought, salinity, insect pests, diseases and seed quality: high temperature has emerged as a major threat to cotton productivity. It is estimated that the global temperature is increasing by $0.4 \sim 0.8^{\circ} \mathrm{C} /$ year (PMD 2016). The consequences of high temperature in cotton could be low germination, higher fruit shedding $\left(\geq 30^{\circ} \mathrm{C} / 22^{\circ} \mathrm{C}\right)$, pollen sterility and abortion (Guilioni et al. 1997; Ismail and Hall 1999), unavailability of macro and micro nutrients due to increase in soil $\mathrm{pH}$, higher levels of $\mathrm{CO}_{2}$ in the air will increase photosynthetic activity resulting in enhanced nutrient requirement of cotton plants.

Keeping in view the importance of emerging threat of climate change, it is need of the day to develop climate smart varieties of cotton which could withstand harsh climatic conditions particularly heat stress due to significant adverse effects on yield of seed cotton. So, this experiment was conducted to explore and understand the genetic mechanisms controlling resistance to high temperature and to identify the potential germplasm having tolerance against heat stress which could be used in breeding programs for the introgression and development of new germplasm of upland cotton.

\section{Materials and methods}

\section{Screening of germplasm for heat tolerance}

The germplasm consisting of 80 accessions of cotton was collected from various Agricultural Research Institutes and Centers of Pakistan to determine heat tolerant and susceptible parental genotypes. Relative cell injury (RCI) percentage was calculated by using the following formula proposed by Sullivan (1972).

$$
\mathrm{RCI} \%=[1-[(1-(\mathrm{T} 1-\mathrm{T} 2))] /(1-(\mathrm{C} 1 / \mathrm{C} 2))]] \times 100
$$

Where, "T" is EC of heat treated and " $C$ " is EC of controlled samples, subscripts 1 and 2 represent initial and final EC readings, respectively.

Based on means from RCI, two heat tolerant, namely VH-259 and FH-142, and two susceptible genotypes, namely $\mathrm{VH}-282$ and $\mathrm{DNH}-40$ were identified against high temperature (Table 1). First part of this study about the details of 80 accessions and screening procedure has already been published (Salman et al. 2016).

\section{Development of populations}

The four genotypes were hybridized which are named as cross-1 (VH-282 $\times$ FH-142) and cross- 2 (DNH-40 $\times$ VH259 ) in the manuscript. A crossing scheme was designed for the development of various populations, i.e., $F_{1}, F_{2}$, $\mathrm{BC}_{1}$ and $\mathrm{BC}_{2}$ to fulfill the criteria of generation mean analysis. $\mathrm{BC}_{1}$ populations were developed by keeping $\mathrm{F}_{1}$ as female parent and parent 1 as male parent, whereas $\mathrm{BC}_{2}$ was developed by using $\mathrm{F}_{1}$ as female parent and parent 2 as a male parent. Some of flowers were selfpollinated for the development of seed for $F_{2}$ population. These populations were developed by using greenhouse and field facilities of the Department.

Table 1 List of identified heat tolerant and susceptible genotypes of $G$. hirsutum L.

\begin{tabular}{lll}
\hline Sr. No. & Genotypes & Response \\
\hline 1 & VH-259 & High cell membrane stability \\
2 & FH-142 & High cell membrane stability \\
3 & VH-282 & Low cell membrane stability \\
4 & DNH-40 & Low cell membrane stability \\
\hline
\end{tabular}


Table 2 Generation means for boll weight, gin turn out, fibre length, fibre strength, fibre fineness and relative cell injury in two crosses $\mathrm{VH}-282 \times \mathrm{FH}-142$ (1) and $\mathrm{DNH}-40 \times \mathrm{VH}-259$ (2) under normal $(\mathrm{N})$ and heat stress $(\mathrm{H})$ conditions

\begin{tabular}{|c|c|c|c|c|c|c|c|c|}
\hline \multirow[t]{2}{*}{ Traits } & \multirow{2}{*}{$\begin{array}{l}\text { Stress } \\
\text { Levels }\end{array}$} & \multicolumn{6}{|c|}{ Generation Means } & \multirow{2}{*}{$\begin{array}{l}\text { Pop } \\
\text { Effect }\end{array}$} \\
\hline & & $\overline{P_{1}}$ & $\mathrm{P}_{2}$ & $F_{1}$ & $\mathrm{BC}_{1}$ & $\mathrm{BC}_{2}$ & $\mathrm{~F}_{2}$ & \\
\hline \multirow[t]{4}{*}{ BW } & N1 & 3.50 & 3.46 & 3.63 & 3.56 & 3.61 & 3.59 & * \\
\hline & $\mathrm{H} 1$ & 3.43 & 3.38 & 4.00 & 2.08 & 2.57 & 3.33 & * \\
\hline & N2 & 3.14 & 3.13 & 3.62 & 3.12 & 3.30 & 3.45 & * \\
\hline & $\mathrm{H} 2$ & 3.40 & 3.12 & 3.53 & 3.32 & 3.17 & 3.22 & * \\
\hline \multirow[t]{4}{*}{ GOT } & N1 & 39.63 & 39.78 & 39.44 & 38.27 & 38.23 & 39.19 & $* *$ \\
\hline & $\mathrm{H} 1$ & 38.25 & 38.28 & 38.39 & 38.31 & 38.33 & 38.28 & $* *$ \\
\hline & N2 & 39.55 & 38.89 & 39.11 & 37.11 & 38.41 & 37.98 & $* *$ \\
\hline & $\mathrm{H} 2$ & 38.60 & 37.33 & 39.46 & 37.94 & 38.35 & 37.69 & $* *$ \\
\hline \multirow[t]{4}{*}{$\mathrm{FL}$} & N1 & 24.98 & 24.74 & 24.71 & 24.31 & 25.25 & 23.31 & $* *$ \\
\hline & $\mathrm{H} 1$ & 26.97 & 27.51 & 28.05 & 26.94 & 27.30 & 26.91 & $* *$ \\
\hline & N2 & 26.91 & 27.53 & 27.93 & 27.10 & 27.21 & 26.97 & $* *$ \\
\hline & $\mathrm{H} 2$ & 26.88 & 26.75 & 27.77 & 27.10 & 27.00 & 27.18 & $* *$ \\
\hline \multirow[t]{4}{*}{ FS } & N1 & 25.06 & 24.63 & 24.92 & 24.61 & 24.90 & 23.19 & $* *$ \\
\hline & $\mathrm{H} 1$ & 25.17 & 24.55 & 24.75 & 23.52 & 24.22 & 23.95 & $* *$ \\
\hline & N2 & 24.70 & 24.65 & 24.55 & 24.54 & 24.52 & 24.53 & $* *$ \\
\hline & $\mathrm{H} 2$ & 24.91 & 24.33 & 24.67 & 24.66 & 24.64 & 24.56 & $* *$ \\
\hline \multirow[t]{4}{*}{$\mathrm{FF}$} & N1 & 4.30 & 4.26 & 4.32 & 4.33 & 4.37 & 4.28 & * \\
\hline & $\mathrm{H} 1$ & 4.24 & 4.29 & 4.20 & 4.68 & 4.47 & 4.47 & * \\
\hline & N2 & 4.30 & 4.21 & 4.25 & 4.40 & 4.26 & 4.46 & * \\
\hline & $\mathrm{H} 2$ & 4.27 & 4.28 & 4.29 & 4.49 & 4.44 & 4.47 & * \\
\hline \multirow[t]{4}{*}{$\mathrm{RCl}$} & N1 & 28.30 & 28.45 & 21.86 & 26.66 & 26.57 & 26.97 & $* *$ \\
\hline & $\mathrm{H} 1$ & 24.27 & 37.17 & 25.67 & 35.23 & 36.73 & 32.48 & $* *$ \\
\hline & $\mathrm{N} 2$ & 25.36 & 25.32 & 21.47 & 31.27 & 29.94 & 28.34 & ** \\
\hline & $\mathrm{H} 2$ & 24.78 & 35.02 & 25.72 & 33.79 & 33.93 & 32.01 & $* *$ \\
\hline
\end{tabular}

\section{Assessment of populations for heat stress}

Average daily temperature during summer season of last five years was collected from AgriMet to determine the duration of maximum heat stress during cotton crop. By having this information all of populations from cross-1 and cross-2 alongwith parents were planted during 20162017 on two different sowing times, i.e., early and late. These two sowings were planned based on temperature data of last ten years. The flowering stage in early sowing coincides with maximum annual temperature whereas late sowing coincides with optimal temperature (Ahamed et al. 2010; Abro et al. 2015). The plant material was sown in the experimental area of the department in triplicate by following randomized complete block design. During planting, plant to plant and row to row distance were maintained at $30 \mathrm{~cm}$ and $75 \mathrm{~cm}$, respectively, for optimal supply of nutrition and plant protection practices to get good population except effects of heat stress. At the time of reproductive stage RCI \%, boll weight and fiber traits were determined.

\section{Statistical analysis}

Analysis of variance among the generations was conducted according to Steel et al. (1997). The populations showing significant differences for certain traits were used to conduct generation mean analysis by following the method described by Mather and Jinks (2013).

\section{Results}

Assessment of populations

Mean values of $\mathrm{F}_{1}$ were higher than $\mathrm{F}_{2}, \mathrm{BC}_{1}$ and $\mathrm{BC}_{2}$ populations for all of the traits included in this study except fiber fineness and RCI for both crosses under normal and stress conditions (Table 2). The range of boll

Table 3 Genetic effects for boll weight, ginning outturn, fibre length, fibre strength, fibre fineness and relative cell injury in cross $\mathrm{VH}-282 \times \mathrm{FH}-142(1)$ under normal $(\mathrm{N})$ and heat stress $(\mathrm{H})$

\begin{tabular}{|c|c|c|c|c|c|c|c|c|}
\hline \multirow[t]{2}{*}{ Traits } & & \multicolumn{6}{|c|}{ Genetic Effects } & \multirow[t]{2}{*}{$X^{2}(D F)$} \\
\hline & & $\mathrm{m} \pm \mathrm{S} . \mathrm{E}$ & {$[\mathrm{d}] \pm$ S.E. } & {$[h] \pm$ S.E. } & {$[i] \pm$ S.E. } & {$[j] \pm$ S.E. } & {$[I] \pm$ S.E. } & \\
\hline \multirow[t]{2}{*}{ BW } & N1 & $3.50 \pm 0.04$ & $0.02 \pm 0.04$ & $0.16 \pm 0.07$ & - & - & - & $1.77(3)$ \\
\hline & $\mathrm{H} 1$ & $2.93 \pm 0.03$ & - & - & $0.43 \pm 0.06$ & $-1.38 \pm 0.13$ & - & $2.62(3)$ \\
\hline \multirow[t]{2}{*}{ GOT } & N1 & $37.86 \pm 0.40$ & - & - & $1.84 \pm 0.52$ & $-1.91 \pm 0.82$ & $1.58 \pm 0.68$ & $0.07(2)$ \\
\hline & $\mathrm{H} 1$ & $38.26 \pm 0.14$ & - & - & - & $-0.03 \pm 0.78$ & - & $0.10(4)$ \\
\hline \multirow[t]{2}{*}{$\mathrm{FL}$} & N1 & $24.19 \pm 0.10$ & $0.93 \pm 0.18$ & - & - & - & - & $6.26(4)$ \\
\hline & $\mathrm{H} 1$ & $26.57 \pm 0.30$ & $0.27 \pm 0.22$ & - & $0.67 \pm 0.41$ & $1.30 \pm 0.74$ & $1.48 \pm 0.54$ & $0.00(1)$ \\
\hline \multirow[t]{2}{*}{ FS } & N1 & $26.76 \pm 1.57$ & $0.21 \pm 0.10$ & $-6.77 \pm 3.60$ & $-1.92 \pm 1.57$ & $3.35 \pm 0.80$ & $4.92 \pm 2.09$ & $000(0)$ \\
\hline & $\mathrm{H} 1$ & $23.30 \pm 0.28$ & $0.30 \pm 0.09$ & - & $1.56 \pm 0.31$ & - & $1.46 \pm 0.34$ & $0.20(2)$ \\
\hline \multirow[t]{2}{*}{ FF } & N1 & $4.34 \pm 0.05$ & - & $0.07 \pm 0.10$ & - & - & - & $7.12(4)$ \\
\hline & $\mathrm{H} 1$ & $5.18 \pm 0.21$ & $0.02 \pm 0.05$ & $-0.98 \pm 0.26$ & $-0.91 \pm 0.23$ & - & - & $0.03(2)$ \\
\hline \multirow[t]{2}{*}{$\mathrm{RCl}$} & N1 & $71.62 \pm 0.50$ & - & - & - & $0.82 \pm 2.77$ & $6.51 \pm 1.03$ & $0.02(3)$ \\
\hline & $\mathrm{H} 1$ & $66.79 \pm 6.23$ & $6.45 \pm 0.55$ & $-15.61 \pm 14.36$ & $2.50 \pm 6.20$ & $-21.41 \pm 3.32$ & $23.16 \pm 8.45$ & $000(0)$ \\
\hline
\end{tabular}


Table 4 Genetic effects for boll weight, ginning outturn, fibre length, fibre strength, fibre fineness and relative cell injury in cross $\mathrm{DNH}-40 \times \mathrm{VH}-259(2)$ under normal $(\mathrm{N})$ and heat stress $(\mathrm{H})$

\begin{tabular}{|c|c|c|c|c|c|c|c|c|}
\hline \multirow[t]{2}{*}{ Traits } & & \multicolumn{6}{|c|}{ Genetic Effects } & \multirow[t]{2}{*}{$\overline{X^{2}(D F)}$} \\
\hline & & $m \pm S . E$. & {$[\mathrm{d}] \pm$ S.E. } & {$[\mathrm{h}] \pm$ S.E. } & {$[i] \pm$ S.E. } & {$[j] \pm S . E$.} & {$[l] \pm$ S.E. } & \\
\hline \multirow[t]{2}{*}{ BW } & N2 & $2.01 \pm 0.27$ & $0.03 \pm 0.03$ & $2.84 \pm 0.61$ & $1.12 \pm 0.27$ & - & $-1.24 \pm 0.35$ & $1.86(1)$ \\
\hline & $\mathrm{H} 2$ & $3.26 \pm 0.05$ & $0.14 \pm 0.05$ & $-0.39 \pm 0.23$ & - & $-0.33 \pm 0.20$ & $0.67 \pm 0.23$ & $2.03(1)$ \\
\hline \multirow[t]{2}{*}{ GOT } & N2 & $35.16 \pm 0.87$ & $0.35 \pm 0.22$ & $3.96 \pm 1.17$ & $4.05 \pm 0.95$ & - & - & $0.05(2)$ \\
\hline & $\mathrm{H} 2$ & $37.96 \pm 0.26$ & $0.63 \pm 0.22$ & $-1.34 \pm 1.09$ & - & - & $2.84 \pm 1.11$ & $0.02(2)$ \\
\hline \multirow[t]{2}{*}{$\mathrm{F}$} & N2 & $27.79 \pm 1.38$ & $0.12 \pm 0.18$ & $-2.90 \pm 3.05$ & $-0.57 \pm 1.36$ & - & $3.04 \pm 1.80$ & $2.04(1)$ \\
\hline & $\mathrm{H} 2$ & $26.81 \pm 0.13$ & - & - & - & - & $1.06 \pm 0.29$ & $6.20(4)$ \\
\hline \multirow[t]{2}{*}{ FS } & N2 & $24.53 \pm 0.11$ & - & - & $0.15 \pm 0.16$ & - & - & $0.30(4)$ \\
\hline & $\mathrm{H} 2$ & $24.64 \pm 0.07$ & $0.28 \pm 0.10$ & - & - & - & - & $0.29(4)$ \\
\hline \multirow[t]{2}{*}{$\mathrm{FF}$} & N2 & $4.46 \pm 0.14$ & $0.05 \pm 0.05$ & - & $-0.20 \pm 0.15$ & $-0.52 \pm 0.32$ & $-0.21 \pm 0.17$ & $0.00(1)$ \\
\hline & $\mathrm{H} 2$ & $4.28 \pm 0.05$ & $0.02 \pm 0.05$ & $0.06 \pm 0.28$ & - & - & $-0.02 \pm 0.27$ & $0.19(2)$ \\
\hline \multirow[t]{2}{*}{$\mathrm{RCl}$} & N2 & $66.17 \pm 6.81$ & - & $-9.94 \pm 16.84$ & $8.49 \pm 6.78$ & $-3.20 \pm 3.94$ & $14.47 \pm 9.86$ & $0.12(1)$ \\
\hline & $\mathrm{H} 2$ & $66.83 \pm 7.17$ & $5.12 \pm 0.63$ & & $3.27 \pm 7.14$ & $-14.08 \pm 4.09$ & $17.38 \pm 10.03$ & $000(0)$ \\
\hline
\end{tabular}

Note: $\mathrm{m}=$ mean, $\mathrm{d}=$ additive effect, $\mathrm{h}=$ dominant effect, $\mathrm{i}=$ additive $\times$ additive, $\mathrm{j}=$ additive $\times$ dominance, $\mathrm{I}=$ dominance $\times$ dominance

weight was found to be $2.08 \sim 4 \mathrm{~g}$, GOT $37.11 \sim 39 \%$, fiber length $23.31 \sim 28.05 \mathrm{~mm}$, fiber strength $23.52 \sim 25.17$ g.tex ${ }^{-1}$ and fiber fineness $4.21 \sim 4.68 \mu \mathrm{g} \cdot \mathrm{inch}^{-1}$ for all of population derived from two crosses under normal and heat stress conditions.

\section{Genetic effects}

The additive [d) and dominant [h] effects were statistically significant for boll weight and fiber strength in normal conditions while $\mathrm{d}$ and $\mathrm{h}$ were involved in the inheritance of fiber fineness and relative cell injury in heat stressed condition in cross-1 (Tables 3 and 4). In cross-2, additive and dominant effects were significant for boll weight and GOT in normal and heat stressed conditions, for fiber length in normal condition, for fiber fineness and relative cell injury in heat stressed condition. It indicates that both additive and dominant genes played an important role in inheritance of these traits.

Dominance $[\mathrm{h}]$, additive $\times$ dominance [j] and dominance $\times$ dominance [l] variances referred as non-additive gene action, were significant for RCI under heat stress in cross-1, and this pattern of inheritance was found for boll weight under heat stress and RCI under both normal and heat stress condition in case of cross-2. This indicated that these traits were affected by dominance as main affect and epistasis as interallelic interaction.

\section{Correlation}

Genotypic correlation was lower than phenotypic correlation that showed involvement of environmental $x$

Table 5 Phenotypic (lower diagonal) and genetic correlation (upper diagonal) matrix for boll weight, ginning outturn, fibre length, fibre strength, fibre fineness and relative cell injury in cross VH-282 $\times \mathrm{FH}-142(1)$ under normal $(\mathrm{N})$ and heat stress $(\mathrm{H})$ conditions

\begin{tabular}{|c|c|c|c|c|c|c|c|}
\hline TRAITS & Stress Conditions & BW & GOT & $\mathrm{FL}$ & FS & $\mathrm{FF}$ & $\mathrm{RCl}$ \\
\hline \multirow[t]{2}{*}{ BW } & N1 & & 0.205 & -0.394 & -0.029 & -0.22 & -0.034 \\
\hline & $\mathrm{H} 1$ & & 0.077 & 0.374 & 0.026 & 0.11 & -0.129 \\
\hline \multirow[t]{2}{*}{ GOT } & N1 & -0.068 & & 0.382 & 0.016 & -0.015 & 0.1 \\
\hline & $\mathrm{H} 1$ & -0.034 & & -0.092 & -0.029 & 0.269 & -0.25 \\
\hline \multirow[t]{2}{*}{$\mathrm{FL}$} & N1 & 0.031 & 0.103 & & -0.175 & -0.107 & -0.155 \\
\hline & $\mathrm{H} 1$ & 0.019 & 0.092 & & 0.038 & 0.385 & -0.088 \\
\hline \multirow[t]{2}{*}{ FS } & N1 & -0.013 & -0.073 & 0.156 & & -0.254 & -0.029 \\
\hline & $\mathrm{H} 1$ & 0.082 & -0.048 & -0.045 & & -0.212 & 0.07 \\
\hline \multirow[t]{2}{*}{$\mathrm{FF}$} & N1 & 0.132 & 0.013 & 0.026 & 0.009 & & -0.057 \\
\hline & $\mathrm{H} 1$ & -0.042 & -0.075 & -0.082 & -0.113 & & -0.228 \\
\hline \multirow[t]{2}{*}{$\mathrm{RCl}$} & N1 & -0.096 & 0.043 & -0.005 & -0.051 & 0.049 & \\
\hline & $\mathrm{H} 1$ & $-0.266^{* *}$ & 0.034 & -0.01 & -0.039 & -0.02 & \\
\hline
\end{tabular}

*and ${ }^{* *}$ mean significant differences at $5 \%$ and $1 \%$ probability levels, respectively 
Table 6 Phenotypic (lower diagonal) and genetic correlation (upper diagonal) matrix for boll weight, ginning outturn, fibre length, fibre strength, fibre fineness and relative cell injury in cross DNH-40 $\times \mathrm{VH}-259$ (2) under normal (N) and heat stress (H) conditions

\begin{tabular}{|c|c|c|c|c|c|c|c|}
\hline TRAITS & Stress Conditions & BW & GOT & $\mathrm{FL}$ & FS & $\mathrm{FF}$ & $\mathrm{RCl}$ \\
\hline \multirow[t]{2}{*}{ BW } & $\mathrm{N} 2$ & & 0.159 & -0.124 & -0.127 & 0.092 & -0.242 \\
\hline & $\mathrm{H} 2$ & & 0.234 & -0.02 & 0.177 & 0.18 & -0.048 \\
\hline \multirow[t]{2}{*}{ GOT } & $\mathrm{N} 2$ & -0.011 & & -0.191 & 0.000 & -0.205 & -0.072 \\
\hline & $\mathrm{H} 2$ & -0.056 & & 0.059 & -0.031 & -0.103 & -0.068 \\
\hline \multirow[t]{2}{*}{$\mathrm{FL}$} & N2 & 0.039 & 0.013 & & -0.213 & 0.41 & -0.34 \\
\hline & $\mathrm{H} 2$ & 0.001 & 0.123 & & -0.13 & 0.073 & -0.489 \\
\hline \multirow[t]{2}{*}{ FS } & $\mathrm{N} 2$ & 0.054 & -0.065 & -0.03 & & -0.173 & -0.092 \\
\hline & $\mathrm{H} 2$ & 0.026 & -0.003 & -0.01 & & -0.272 & -0.165 \\
\hline \multirow[t]{2}{*}{$\mathrm{FF}$} & $\mathrm{N} 2$ & 0.11 & -0.01 & -0.079 & -0.011 & & -0.167 \\
\hline & $\mathrm{H} 2$ & -0.144 & 0.056 & -0.024 & -0.027 & & -0.015 \\
\hline \multirow[t]{2}{*}{$\mathrm{RCl}$} & $\mathrm{N} 2$ & -0.088 & -0.124 & -0.043 & -0.081 & 0.035 & \\
\hline & $\mathrm{H} 2$ & -0.067 & $-0.197^{*}$ & -0.007 & -0.084 & 0.035 & \\
\hline
\end{tabular}

*mean significant differences at $5 \%$ probability level

genotypic interaction. The correlation analysis revealed that boll weight was significantly but negatively correlated with cell membrane stability at phenotypic level grown in heat stress condition for cross-1 (Table 5 and Fig. 1). Likewise, in cross-2, GOT was also negatively and significantly correlated with relative cell injury under heat stress condition (Table 6 and Fig. 1).

\section{Heritability and genetic advance}

Narrow sense heritability was moderate (0.43-0.74) whereas broad sense heritability was found high (0.760.96) in both crosses (Table 7 \& Fig. 2). Narrow sense heritability was lower than broad sense heritability for all the traits under study in both crosses. Genetic advance was low to moderate for both the crosses under both normal and heat stress conditions and ranged from 0.52 to 16.91 (Table 7 \& Fig. 2).

\section{Heterosis}

Heterosis and Heterobeltiosis was statistically significant for boll weight under heat stress condition for cross-1, while it was significant for cross-2 in normal condition. The values of heterosis and heterobeltiosis were ranged from -0.2 to 17.47 and -0.24 to 16.73 , respectively, for both crosses under normal and heat stress conditions (Table 7).

\section{Discussion}

Cotton production is facing several biotic and abiotic challenges including CLCV (Cotton leaf curl virus), wilting disease, sucking and chewing insect pests, drought and elevated temperature. In recent years, high temperature has been reported as a serious threat to crop productivity (Zafar et al. 2018). So, when cotton is exposed to high temperature for longer duration lead to wilting of leaf (Ahuja et al. 2010; Zahid et al. 2016), shedding of fruiting bodies, i.e., squares,

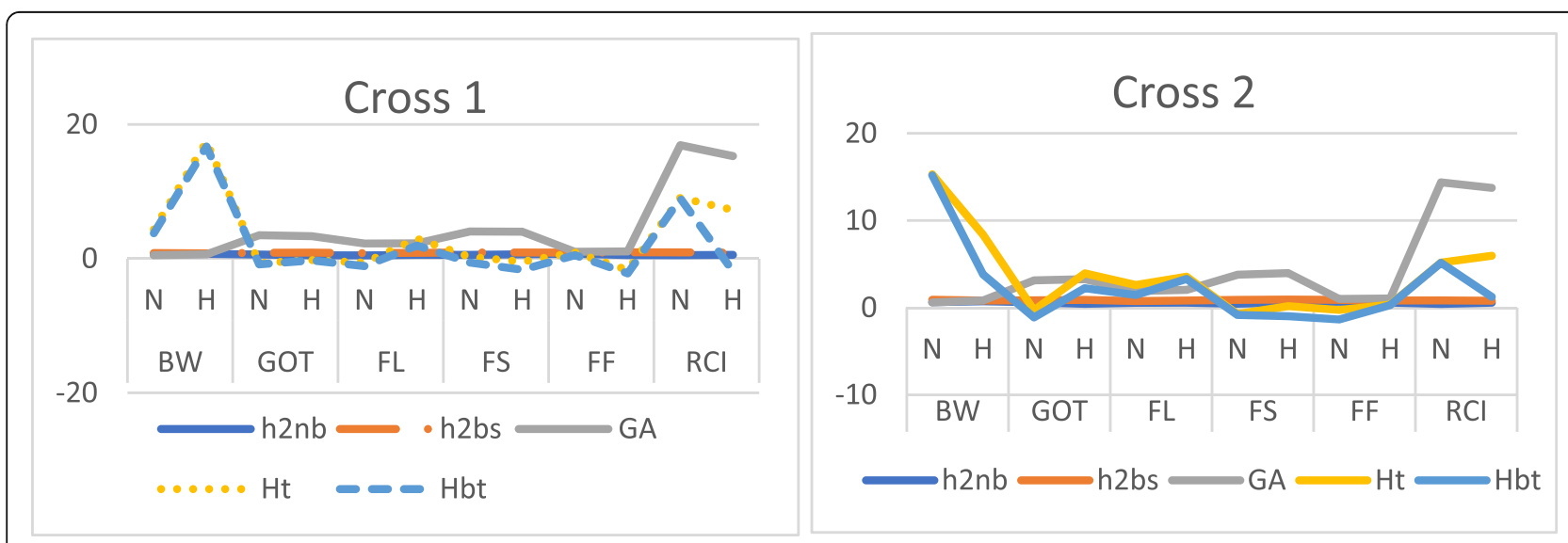

Fig. 1 Correlation coefficients under normal(N) and heat stressed $(\mathrm{H})$ conditions for cross-1 and cross-2 
Table 7 Narrow sense heritability ( $\left.h^{2} n s\right)$, broad sense heritability ( $h^{2}$ bs), Genetic Advance (GA), Heterosis (Ht) and Better parent heterosis (Hbt) for boll weight, ginning outturn, fibre length, fibre strength, fibre fineness and relative cell injury in $\mathrm{VH}-282 \times \mathrm{FH}-142$

\begin{tabular}{|c|c|c|c|c|c|c|c|c|c|c|c|}
\hline \multirow[t]{2}{*}{ Traits } & \multirow{2}{*}{$\begin{array}{l}\text { Stress } \\
\text { Conditions }\end{array}$} & \multicolumn{5}{|c|}{ Cross-1 } & \multicolumn{5}{|c|}{ Cross-2 } \\
\hline & & $\overline{\mathrm{h}^{2}{ }_{\mathrm{nb}}}$ & $h^{2}$ bs & $G A$ & $\mathrm{Ht}$ & $\mathrm{Hbt}$ & $\overline{h_{n b}^{2}}$ & $h^{2}$ bs & $\mathrm{GA}$ & $\mathrm{Ht}$ & $\mathrm{Hbt}$ \\
\hline \multirow[t]{2}{*}{ BW } & $\mathrm{N}$ & 0.66 & 0.86 & 0.52 & 4.36 & 3.81 & 0.64 & 0.91 & 0.60 & $15.30^{*}$ & $15.18^{*}$ \\
\hline & $\mathrm{H}$ & 0.71 & 0.81 & 0.65 & $17.47^{*}$ & $16.73^{*}$ & 0.74 & 0.82 & 0.83 & 8.38 & 3.82 \\
\hline \multirow[t]{2}{*}{ GOT } & $N$ & 0.62 & 0.89 & 3.49 & -0.66 & -0.84 & 0.63 & 0.85 & 3.13 & -0.28 & -1.11 \\
\hline & $\mathrm{H}$ & 0.51 & 0.92 & 3.35 & -0.20 & -0.24 & 0.44 & 0.90 & 3.27 & 3.94 & 2.24 \\
\hline \multirow[t]{2}{*}{$\mathrm{FL}$} & $N$ & 0.49 & 0.84 & 2.27 & -0.60 & -1.09 & 0.57 & 0.76 & 1.90 & 2.61 & 1.46 \\
\hline & $\mathrm{H}$ & 0.57 & 0.89 & 2.28 & 2.98 & 1.97 & 0.58 & 0.82 & 2.05 & 3.56 & 3.31 \\
\hline \multirow[t]{2}{*}{ FS } & $N$ & 0.56 & 0.93 & 4.05 & 0.28 & -0.57 & 0.45 & 0.89 & 3.79 & -0.72 & -0.83 \\
\hline & $\mathrm{H}$ & 0.64 & 0.94 & 4.01 & -0.43 & -1.65 & 0.61 & 0.93 & 3.97 & 0.19 & -0.98 \\
\hline \multirow[t]{2}{*}{$\mathrm{FF}$} & $\mathrm{N}$ & 0.72 & 0.91 & 1.02 & 0.94 & 0.54 & 0.69 & 0.90 & 1.01 & -0.26 & -1.34 \\
\hline & $\mathrm{H}$ & 0.54 & 0.96 & 1.08 & -1.68 & -2.18 & 0.59 & 0.82 & 1.06 & 0.36 & 0.29 \\
\hline \multirow[t]{2}{*}{$\mathrm{RCl}$} & $N$ & 0.52 & 0.95 & 16.91 & 9.09 & 8.98 & 0.43 & 0.83 & 14.39 & 5.18 & 5.16 \\
\hline & $\mathrm{H}$ & 0.56 & 0.91 & 15.30 & 7.28 & -1.85 & 0.58 & 0.80 & 13.75 & 5.96 & 1.25 \\
\hline
\end{tabular}

*mean significant differences at $5 \%$ probability level

buds, flowers and bolls (Cao et al. 2008; Iqbal et al. 2017), and decreased rate of photosynthesis is reported by Marchand et al. (2005). Therefore, it is need of the time to focus on development of new germplasm which can cope with high temperature.

The biometrical analysis indicated that values of dominance or epistasis were many times greater than those of additive effects which shows that these traits were governed by non-additive gene action (Ahmad et al. 2009; Batool et al. 2013; Iqbal et al. 2013). In contrary, these traits had higher values of broad sense heritability but low values of genetic advance which further elaborated the role of non-additive gene action (Singh and Verma 2018). According to Jagtap (1986) when dominant effects are larger than the additive ones then the intensive selection is required for improvement of these traits and selection may be delayed in later generations. Lower values of narrow sense heritability than broad sense heritability for these traits showed that the environmental component was contributing significantly. Low heritability under heat stress condition validate the role of environmental component as well as genotypic $\times$ environmental interaction (Murtaza 2006; Desalegn et al. 2009; Batool et al. 2010).

Correlation study revealed that the boll weight (Farooq et al. 2014) and GOT (Azhar et al. 1999; Farooq et al. 2014) had a significant and negative phenotypic correlation with RCI under heat stress conditions. Under heat stress RCI was increased which resulted in increased transpiration and less assimilation of photosynthates which had an adverse effect on boll weight and GOT. Consequently, injury of cell membrane lead to the disturbance of normal functioning of cell which exerts adverse effects on synthesis of fiber. The information from heterosis help plant breeders to identify the superior parental and certain combinations for the development of hybrids. The same data was also exploited for heterosis where it was known that boll weight had significant and positive values over mid parent and better parent under heat stress condition.

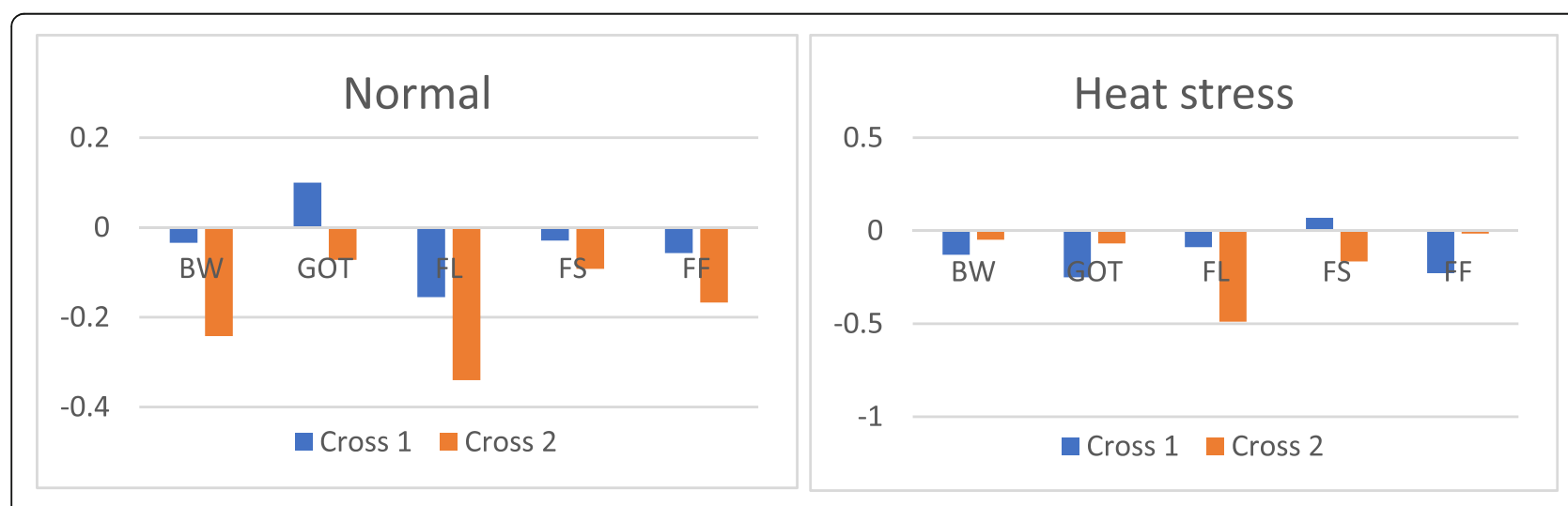

Fig. 2 Heritability, genetic advance and heterosis for cross-1 and cross-2 
This revealed that heterozygosity could increase the weight of boll in cotton. A significant gain in boll weight due to heterosis has been reported by several researchers (Abd-El-Haleem et al. 2010; Panni et al. 2012; El-Refaey and El-Razek 2013). Th progeny from cross-1 exhibited high heterosis under heat stressed condition due to the involvement of heat tolerant donor parent, i.e., FH-142. The germplasm derived from cross-1 had higher values for majority of the traits under heat stress which showed that this particular combination was comparatively more heat tolerant than cross-2. On the basis of these results one could conclude that FH-142 and VH-282 could be the desirable parents for their utilization in the breeding programs for the development of heat tolerant germplasm.

\section{Conclusion}

All of traits studied in this experiment were predominantly controlled by non-additive gene action except RCI where additive gene action was involved. Therefore, selection based on RCI could be reliable for development of heat tolerant varieties. It is determined that heat stress had role in reduction of boll weight and GOT, which are important yield contributing parameters. The parental lines VH-282 and FH-142 performed better under normal and heat stress conditions and could be utilized for the development of new germplasm for high temperature areas in addition fiber related parameters can be improved.

\section{Abbreviations \\ BW: Boll weight; d: Additive effect; FF: Fiber fineness; FL: Fiber length; FS: Fiber strength; GOT: Ginning outturn; h: Dominant effect; i: Additive $\times$ additive; j: Additive $\times$ dominance; I: Dominance $\times$ dominance; m: Mean; RCl: Relative cell injury}

\section{Acknowledgements}

Authors are thankful to Higher Education Commission, Pakistan for provision of funds through Indigenous 5000 PhD Scholarship Scheme.

\section{Authors' contributions}

Salman M conducted this study for his PhD research and collected the data. Azhar MT and Rana IA designed this study and served as supervisory committee for PhD studies of Salman M. Magsood RH and Zia ZU helped in collection of the data and biometrical analysis. While Ahmad S and Bukhsh A have critically reviewed every section of the manuscript before submission to Journal. All the authors read and approved the final manuscript.

\section{Funding}

The funding for this research was provided by Higher Education Commission, Pakistan.

\section{Availability of data and materials \\ Data supporting the finding will be provided on demand. For demand of data any one can contact Salman M and Zia ZU through email and institutional addresses}

Ethics approval and consent to participate Not applicable.

\section{Consent for publication}

Not applicable.

\section{Competing interests}

The authors declare that they have no competing interests.

\section{Author details}

1Department of Plant Breeding \& Genetics, University of Agriculture, Faisalabad, Pakistan. ${ }^{2}$ Cotton Research Institute, Multan, Pakistan. ${ }^{3}$ Centre of Agricultural Biochemistry and Biotechnology, University of Agriculture, Faisalabad, Pakistan. ${ }^{4}$ Department of Plant Breeding \& Genetics, Ghazi University, DG Khan, Pakistan.

Received: 14 January 2019 Accepted: 6 June 2019

Published online: 05 July 2019

\section{References}

Abd-El-Haleem SHM, Metwali EMR, Al-Felaly AMM. Genetic analysis of yield and its components of some Egyptian cotton (Gossypium barbadense L.) varieties. World J Agric Sci. 2010;6(5):615-21.

Abro S, Rajput MT, Khan MA, et al. Screening of cotton (Gossypium hirsutum L.) genotypes for heat tolerance. Pak J Bot. 2015;47(6):2085-91.

Ahamed KU, Nahar K, Fujita M. Sowing date mediated heat stress affects the leaf growth and dry matter partitioning in some spring wheat (Triticum aestivum L.) cultivars. IIOAB J. 2010;1:8-16.

Ahmad RT, Malik TA, Khan IA, Jaskani MJ. Genetic analysis of some morphophysiological traits related to drought stress in cotton (Gossypium hirsutum). Int J Agric Biol. 2009;11:235-40.

Ahuja I, de Vos RCH, Bones AM, Hall RD. Plant molecular stress responses face climate change. Trends Plant Sci. 2010;15(12):664-74. https://doi.org/10.1016/ j.tplants.2010.08.002.

Azhar MA, Khan Al, Ishtiaq M. Path coefficient analysis of some advanced generation progenies of Gossypium hirsutum L. Int J Agric Biol. 1999;1:1-3.

Batool S, Khan NU, Gul S, et al. Genetic analysis for yield and yield contributing variables in upland cotton. J Food Agric Environ. 2013;11(3\&4):624-30.

Batool S, Khan NU, Makhdoom K, et al. Heritability and genetic potential of upland cotton genotypes for morphoyield traits. Pak J Bot. 2010; 42: 1057-64

Cao $Y Y$, Duan $H$, Yang LN, et al. Effect of heat stress during meiosis on grain yield of Rice cultivars differing in heat tolerance and its physiological mechanism. Acta Agron Sin. 2008;34(12):2134-42. https://doi.org/10.1016/S18752780(09)60022-5.

El-Refaey RA, El-Razek UAA. Generation mean analysis for yield, its components and quality characteristics in four crosses of Egyptian cotton (Gossypium barbadense L.). Asian J Crop Sci. 2013;5:153-66. https://doi.org/10.3923/ajcs. 2013.153.166.

Desalegn Z, Ratanadilok N, Kaveeta R. Correlation and heritability for yield and fiber quality parameters of Ethiopian cotton ( Gossypium hirsutum L.) estimated from 15 (diallel) crosses. Kasetsart J Nat Sci. 2009; 43: 1-11.

Farooq J, Anwar M, Riaz M, et al. Correlation and path coefficient analysis of earliness, fiber quality and yield contributing traits in cotton (Gossypium hirsutum L.). J Anmi Plant Sci. 2014;24(3):781-90.

Fryxell PA. A Revised Taxonomic Interpretation of Gossypium L. (Malvaceae). Rheedea. 1992;2(2):108-65. NII Article ID (NAID): 10016730878.

Guilioni L, Wery J, Tardieu F. Heat stress-induced abortion of buds and flowers in pea: is sensitivity linked to organ age or to relations between reproductive organs? Ann Bot. 1997;80(2):159-68. https://doi.org/10.1006/anbo.1997.0425.

ICAC(International Cotton Advisory Committee). Cotton this month August, 2018. USA. 2018. https://www.icac.org/News/NewsDetails?Newsld= EAAAAM8Q5OdNifPDBK3gRQaMViHjKVc79nOGOaHzhHmaJike\&Yearld= EAAAANkwEWRCMUaaot3lkv2L6tjf2almz5CrKZNVtU4BW3p0. Posted 1, Aug 2018.

Iqbal M, Naeem M, Rizwan M, et al. Studies of genetic variation for yield related traits in upland cotton. American-Eurasian J Agric Environ Sci. 2013;13(5):6118. https://doi.org/10.5829/idosi.aejaes.2013.13.05.835.

lqbal M, UI-Allah S, Naeem M, et al. Response of cotton genotypes to water and heat stress: from field to genes. Euphytica. 2017;213(6):131. https://doi.org/10. 1007/s10681-017-1916-2.

Ismail AM, Hall AE. Reproductive-stage heat tolerance, leaf membrane thermostability and plant morphology in cowpea. Crop Sci. 1999;39(6):17628. https://doi.org/10.2135/cropsci1999.3961762x.

Jagtap D. Combining ability in upland cotton. Indian J Agric Sci. 1986;57(7): 456-64.

Lu Z, Chen J, Percy RG, Zeiger E. Photosynthetic rate, stomatal conductance and leaf area in two cotton species (Gossypium barbadense and Gossypium hirsutum) and their relation with heat resistance and yield. Funct Plant Biol. 1997;24(5):693-700. https://doi.org/10.1071/PP97056. 
Marchand FL, Mertens S, Kockelbergh F, et al. Performance of high Arctic tundra plants improved during but deteriorated after exposure to a simulated extreme temperature event. Glob Chang Biol. 2005;11(12):2078-89. https:// doi.org/10.1111/j.1365-2486.2005.01046.x.

Mather K, Jinks JL. Biometrical genetics: the study of continuous variation. 3rd ed. Berlin: Springer. 2013. https://doi.org/10.1007/978-1-4899-3406-2.

Murtaza N. Study of gene effects for boll number, boll weight, and seed index in cotton. J Central European Agriculture. 2006; 6: 255-62.

McCarty JC, Jenkins JN, Wu J. Primitive accession derived germplasm by cultivar crosses as sources for cotton improvement. Crop Sci. 2004;44(4):1226-30. https://doi.org/10.2135/cropsci2004.1226.

Panni MK, Khan NU, Fitmawati SB, Bibi M. Heterotic studies and inbreeding depression in $F_{2}$ populations of upland cotton. Pak J Bot. 2012;44(3):1013-20

PCCC (Pakistan Central Cotton Committee). COTISTICS. Ann Cotton Stat Bull. 2017:46(3):32-5.

PMD (Pakistan Metrological Department). Climate and Astronomical Data. 2016; 26(2):47-52.

Salman M, Khan A, Ahmad I, et al. Genetic architecture of relative cell injury and some yield related parameters in Gossypium hirsutum L. Turkish J Field Crops. 2016;21 (2):246-53. https://doi.org/10.17557/tjfc.67345.

Singh N, Verma O. Genetic variability, heritability and genetic advance in rice (Oryza sativa L.) under salt stressed soil. J Pharmacognosy Phytochemistry. 2018;7(3):3114-7.

Steel RG, Torrie JH, Dickey DA. Principles and procedures of statistics: a biological approach. Columbus, OH: McGraw-Hill. 1997.

Wendel JF, Grover CE. Taxonomy and evolution of the cotton genus, Gossypium. In: Cotton. Madison, Wl: American Society of Agronomy, Crop Science Society of America, Soil Science Society of America, Inc. 2015. https://doi.org/ 10.2134/agronmonogr57.2013.0020.

Zafar SA, Noor MA, Waqas MA, et al. Temperature extremes in cotton production and mitigation strategies. In: Past, present and future trends in cotton breeding. IntechOpen, 2018. https://doi.org/10.5772/intechopen.74648.

Zahid KR, Ali F, Shah F, et al. Response and tolerance mechanism of cotton Gossypium hirsutum L. to elevated temperature stress: a review. Frontiers Plant Sci. 2016;7:937. https://doi.org/10.3389/fpls.2016.00937.

Ready to submit your research? Choose BMC and benefit from:

- fast, convenient online submission

- thorough peer review by experienced researchers in your field

- rapid publication on acceptance

- support for research data, including large and complex data types

- gold Open Access which fosters wider collaboration and increased citations

- maximum visibility for your research: over $100 \mathrm{M}$ website views per year

At $\mathrm{BMC}$, research is always in progress.

Learn more biomedcentral.com/submissions 